\title{
Macroeconomic Factors Affect the Electricity Consumption: A Case of ASEAN Countries
}

\author{
Munirah Ramli ${ }^{\text {a }}$, Noriza Mohd Saad ${ }^{\mathrm{b}}$ and Zulkifli Abdullah ${ }^{\mathrm{c}}$ \\ ${ }^{\mathbf{a}, \mathbf{c}}$ College of Business and Accounting, Universiti Tenaga Nasional, 26700 Pahang, Malaysia \\ ${ }^{b}$ Faculty of Business Management, Universiti Teknologi Mara (UiTM) Machang, 18500 Kelantan, Malaysia \\ Email:::amunirah.ramli@uniten.edu.my, ${ }^{\mathrm{b}}$ noriza@uitm.edu.my ${ }^{\mathrm{c}}$ zulkifliabd@uniten.edu.my
}

Article History: Received: 10 November 2020; Revised 12 January 2021 Accepted: 27 January 2021; Published online: 5 April 2021

\begin{abstract}
The ASEAN Centre of Energy (ACE) aims to improve electricity accessibility among all 10 members. Electricity consumption is concerned globally, since it is main intermediate input of production in pursuing economic growth in this era Industrial Revolution 5.0. The motivation of this study is to examine the key elements that derives the electricity consumption in all Association of Southeast Asian Nations (ASEAN) countries from year 2000 to 2018. A panel data is utilized to investigate the relationship between urban population, industrial structure and financial development towards electricity consumption ( $\mathrm{kWh}$ ) using linear regression model (Pooled OLS, Random Effect, and Fixed Effect models). Results found that rapid growth of urban population gives a great impact to electricity consumption. Thailand and Vietnam have the highest positive interception using Fixed Effect model estimation. The findings of this research suggests the government to explore new energy sources to meet the increased demand of electricity while balancing the environmental sustainabilit.
\end{abstract}

Keywords: Electricity Consumption, ASEAN, Panel Data, Urban Population, Industrial Structure, Financial Development.

\section{Introduction}

It is undeniable that the electricity becomes major demand in energy component and exponentially increased over a decade. The transmission of technology urges the consumer to demand more energy while adapting with the expansion of population size and rapid economic expansion. The economy development becomes a driven for nations refashioning the factor input (energy) in order to balance between energy security and sustainability. The accessibility, availability and accessibility of electricity are important keys to guarantee the sustainability of electricity for social, economic and environment indicator [1]. On the same note, ASEAN Centre Energy (ACE) has concerned to face challenges in closing energy access gaps, improving economy recover, and enhancing sustainable energy policy framework [2]. Hence, the government is required to explore more energy source and renewable energy as an alternative in providing a better utility access [3]. Looking inside the majority country which newly industrialization country, Association of Southeast Asian Nations (ASEAN) countries is an interesting case study where dealing with expansion population size and economic growth. International Energy Agency (IEA) also recognizes ASEAN in pursuing Sustainable Development Goals (SDGs), while making energy would access to all population and cleaner to be consumed.

Fig.1. demonstrates the increasing trends of electricity consumption for all ASEAN countries. The largest electricity consumption are among Indonesia, Vietnam, Thailand, Malaysia and Philippines [1]. Indonesia experiences the highest electricity usage associate with a rapid population in ASEAN region around (268.1 mil) [4]. Then, it followed by Vietnam, Thailand and Malaysia (in 2018) reacting to the industrial structure changes in the respective countries. However, what the element that significantly derived the growth of electricity consumption nowadays?

Although many scholars argue that economy growth is essential factor in nation. Examining macroeconomic impact have led to measure consumer welfare and cost of production [5-6]. However, looking to one side only can limit the future uncertainty where we unaware that how does the electricity consumption derived. Thus, this study aims to elaborate the factors attributes to the changes in electricity consumption. In the market, consumer is the main actor in creating an exchange goods and financial flow, where it pumps back into the economy circulation [18].

The macroeconomic determinants for electricity demand in Malaysia and proposed that the urbanization may give reduction electricity consumption through the development and encouragement financing the renewable energy, such the installation of rooftop solar PV [7]. Furthermore, the electricity consumption have a strong relationship with the growth of population because it is crucial for the process of urbanization and improvement in Gross Domestic Product (GDP) [8]. While, the urge of technology and machine equipment such as (lighting, air 
condition and refrigerator) are the reasons why urban consumer tend to be energy intensity. Keho [9] explained the electricity consumption in urban area gives both positive and negative impact through the theory of ecological modernization. In balancing between the nature and modern lifestyle, the wealthier consumer tend to concern the environment sustainability and prefer advance in technology innovation. Ali [10] criticized the lack of urbanization observation in previous study have lead bias in examining the economic growth. In the case of

Figure 1: Electricity Net Consumption (billion kWh)

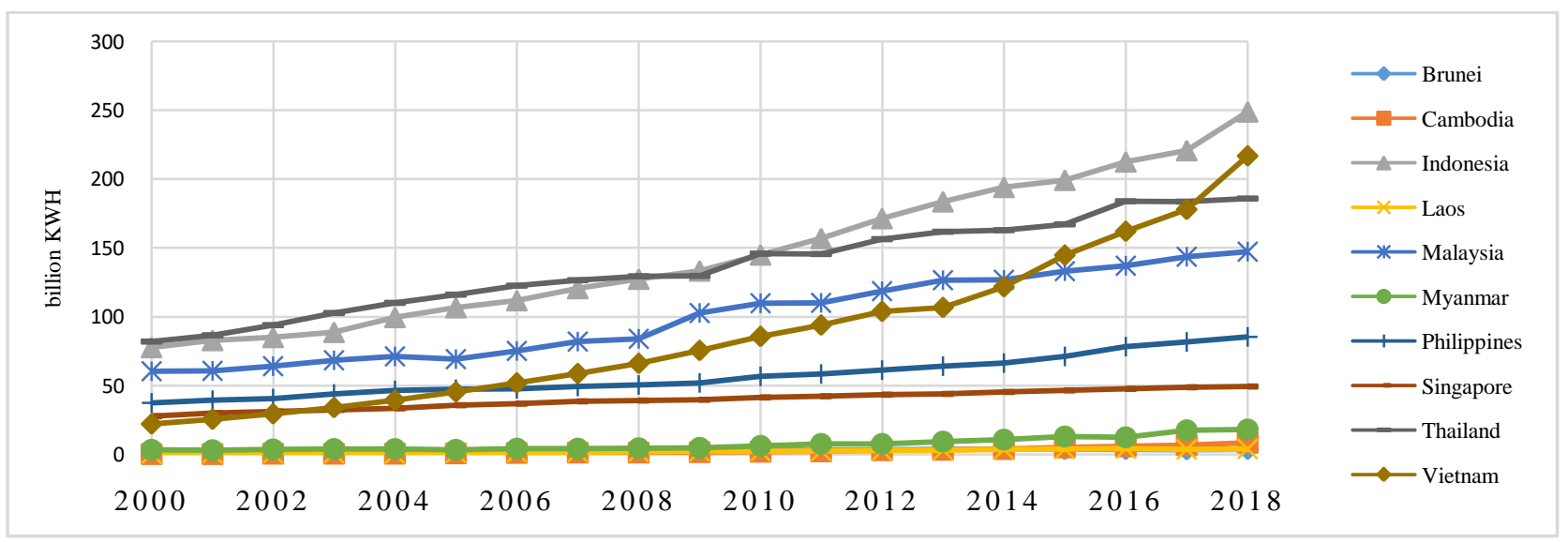

Source: Energy Information Administration (EIA)

Kenya, the power distribution have failed to address electricity demand that influenced by the rapid urban growth.

Electricity is source of social good for overall standard of living and economic development. The production of different sectors are basically required more electricity consumption to drive economic activities such as manufacturing, communication, health and transportation. Besides, the supply of energy always links to pursue the economic development as becomes main input in industrial structure and welfare of living. A diversify used of electricity is to match with modern life that with updated technology and applicants (e.g. chiller, machine and computer). The technology advance can be related to the demand more energy for the capital intensity. The structure output in Gross Domestic Product (GDP) consists of Agriculture, Industrial and Services as a key indicator for all countries [4]. The correlation of industrial output and electricity consumption have strong relationship while digesting the role of input factor for all manufacturing production as the capital intensive industrial [11]. However, the type of technology transfer and nature of employment production can contribute to vary in industrial process and affect the level electricity consumption [12].

Meanwhile, the process of urban population and industrial structure is incomplete without the injection of financial development. The ARDL finding indicates the significant of financial development results are greater impact to the electricity consumption in Tunisia case [13]. According to the World Bank, financial development is essential to extend credit in promoting economic growth through capital formation and innovation progress. Topcu [14] support that the capital formation is the basic component of the economic growth. It is an accumulation of physical capital that required in production efficiency. The interaction of urbanization and financial development will help the countries to reduce carbon emission as the countries also realize to moderate in consuming electricity efficiently [15]. Thus, the important of encouraging investment in energy infrastructure aims to upgrade the technology supplying electricity with clean energy.

\section{Data and Methodology}

\subsection{Data and Sample}

To examine the relationship between electricity consumption and macroeconomic factors, the explanatory variables, which are urban population, industrial structure and financial development are classified as the key indicators in macroeconomic factors which potentially influence the changes of electricity consumption. The data descriptive are summarized in Table 1. The observation focuess to 10 ASEAN countries, such that Brunei, Cambodia, Indonesia, Laos, Malaysia, Myanmar, Philippines, Singapore, Thailand, and Vietnam. The purpose of selecting these countries is to compare the variety pattern in developing and industrialize countries. Furthermore, ASEAN countries are selected because of the sharing of similarity in geography, standard of living and income level. Besides, the effort of each members in enhancing energy connectivity to meet the rapid growing economics and offer more sustainable energy pathway becomes the light for this study in understanding the consumption pattern [2]. Thus, data are extracted from Asian Development Bank (ADB) and Energy Information Administration (EIA), employs panel data 10 countries for the period 2000-2018. 
Table 1: Data Descriptive

\begin{tabular}{clc}
\hline Variables & Symbol & $\begin{array}{c}\text { Unit of } \\
\text { Measurement }\end{array}$ \\
\hline $\begin{array}{c}\text { Electricity } \\
\text { Consumption } \\
\text { Urban } \\
\text { Population }\end{array}$ & EC & Billion kWh \\
$\begin{array}{c}\text { Industrial } \\
\text { Structure }\end{array}$ & IND & $\begin{array}{c}\% \text { of Output GDP } \\
\text { population }\end{array}$ \\
$\begin{array}{c}\text { Financial } \\
\text { Development }\end{array}$ & FD & $\begin{array}{c}\% \text { Gross Capital } \\
\text { Formation of GDP } \\
\text { Current Prices }\end{array}$ \\
\hline
\end{tabular}

\subsection{Multivariate Regression Results}

Panel model is utilized because it capable of controlling heterogeneity, more information, reduce multicollinearity [16-17]. Panel data is also known as longitudinal data that comprised multi-dimensional data and measurement over time. This paper conducts the econometric analysis and using STATA software for interpretation. All variables are transformed into natural log beforehand. Using three different estimation models and then verify with robustness model: model 1: Pooled Ordinary Least Square (POLS), model 2: Random Effect (RE), model 3: Fixed Effect - Within Estimation (FE-WE), and model 4: Robustness.

Thus, the equation for all models POLS, FE, RE and Robust are written respectively as follow:

$$
\begin{aligned}
& E C_{1}=\beta_{0}+\beta_{1} U R B_{i t}+\beta_{2} I N D_{i t}+\beta_{3} F D_{i t}+\varepsilon_{i t} \\
& E C_{2}=\beta_{0}+\beta_{f e_{1}} U R B_{i t}+\beta_{f e_{2}} I N D_{i t}+\beta_{f e_{3}} F D_{i t}+\varepsilon_{i t} \\
& E C_{3}=\beta_{0}+\beta_{r e_{1}} U R B_{i t}+\beta_{r e_{2}} I N D_{i t}+\beta_{r e_{3}} F D_{i t}+\varepsilon_{i t} \\
& E C_{4}=\beta_{0}+\beta_{\text {robust }} U R B_{i t}+\beta_{2} I N D_{i t}+\beta_{3} F D_{i t}+\varepsilon_{i t}
\end{aligned}
$$

This study uses two basic tests to decide appropriate estimator among three. The first test is the Breusch-Pagan Lagragian Multiplier (BP-LM) to test is there heteroscedasticity. Second, the study conduct the Hausman test to choose between RE and FE estimator.

\section{Results and Discussion}

\subsection{Data and Sample}

Submit. The descriptive result is shown in Table 2 for full set of ASEAN countries used in this study. The range of Electricity Consumption begins with minimum of 0.382 billion $\mathrm{kWh}$ (Combodia) to 1,061 billion $\mathrm{kWh}$ (Indonesia). Meanwhile, the mean is 58.101 and the standard deviation is 60.417 indicates that the values for variable electricity consumption data are spread out over a wider range from the mean. This result also explains that the most of countries have higher urban population with average of $48 \%$ except for Cambodia, Laos, Myanmar, and Vietnam.

Urban population of these countries indicate a rapid increase over 18 years, except for Singapore that have reached $100 \%$ while Philippines and Myanmar are relatively slow in urban population growth as refer to Appendix 1. Meanwhile, the range for industrial structure is between 9.7\% (Myanmar in 2000) to 57.7\% (Brunei in 2013), indicates that the government is promoting industrial structure but at the same time balancing between agriculture and services structure. The skewness results of industrial structure also supported the argument of most the countries is around $33.48 \%$. On the other hand, the average percentage for financial development is the lowest compared to all variables with $24.17 \%$ and standard error of 6.772 . Thus, most of countries have limitation in investing in gross capital formation.

Meanwhile, Table 3 shows the correlations between variable, explaining that all variables have positive relationship to Electricity Consumption and the IND have greater correlation with EC, showing that the countries 
with higher percentage in industrial structure required more energy. Note that, the results also published no multicollinearity issues among all variables

Table 2: Descriptive Statistics

\begin{tabular}{|c|c|c|c|c|c|}
\hline Sy & $\mathbf{M}$ & Std. & $\mathbf{M}$ & Ma & Skew \\
\hline mbol & ean & Dev. & in & $\mathbf{x}$ & ness \\
\hline EC & 5 & 60.4 & 0 . & 248 & 0.952 \\
\hline & 8.10 & 17 & 382 & .944 & \\
\hline UR & 4 & 24.3 & 18 & 100 & 0.801 \\
\hline B & 8.61 & 75 & .586 & .000 & \\
\hline IN & 3 & 8.45 & 9. & 57. & - \\
\hline D & 3.48 & 0 & 700 & 770 & 0.079 \\
\hline FD & 2 & 6.67 & 6. & 41. & 0.027 \\
\hline & 4.17 & 2 & 266 & 067 & \\
\hline
\end{tabular}

Notes: $\mathrm{N}=10$ countries, $\mathrm{T}=2000-2018$

Table 3: Correlations Matrix

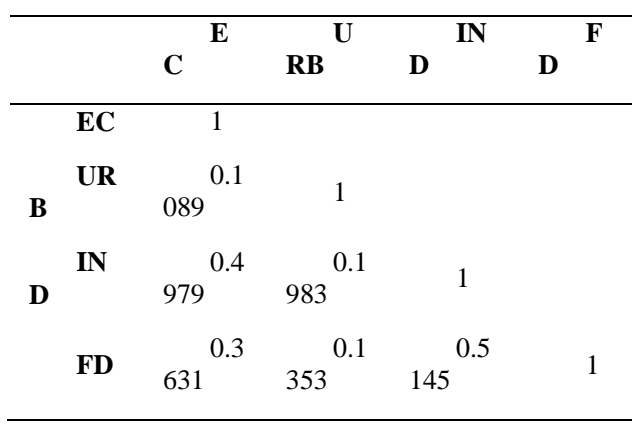

\subsection{Multivariate Regression Results}

The panel regression result are summarized in Table 3. Meanwhile, Fig.2. (a,b,c) show the distribution of each explanatory variable plotted from dependent variable are summarized in Fig.2. (a,b,c). The scatter plot explain the relationship between electricity consumption and industrial structure (Fig.2.b) and financial development (Fig.2.c) are moderately strong positive compared to urban population (Fig.2.a). In general, the electricity consumption in each countries tend to increase as all variables increased.

The result from Hausman test confirms that the FE estimator is most appropriate, as the p-value is $<5 \%$, reject the null hypothesis: no correlation. Therefore, the study only used FE estimator in discussing the results. The Rsquare for model 2 (FE-WE) is the highest compared to POLS with 59\% and $42 \%$ respectively. This shows that the model are strongly relationship between electricity consumption and the explanatory variables. This model also strongly significant as shown in F-test, where $85 \%$ strongly explain the dependent variable changes.

Fig.2.a Scatter Plot Relationship between Urban Population (URB) and Electricity Consumption (EC)

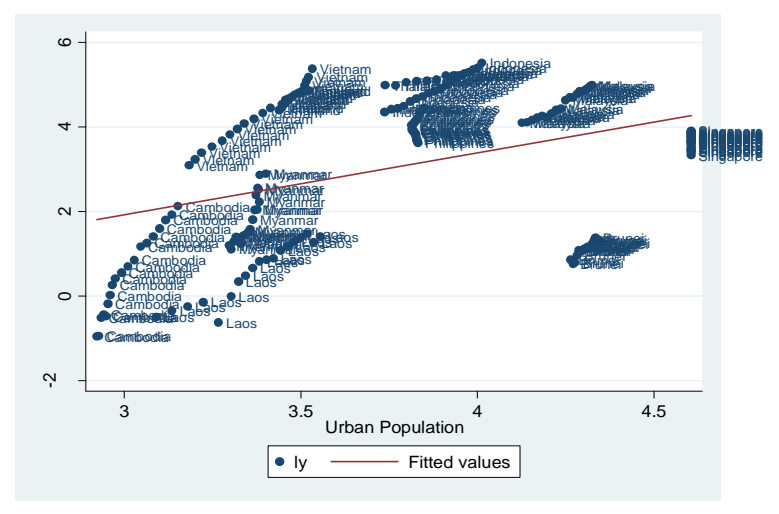


Fig.2.b Scatter Plot Relationship between Industrial Structure (IND) and Electricity Consumption (EC)

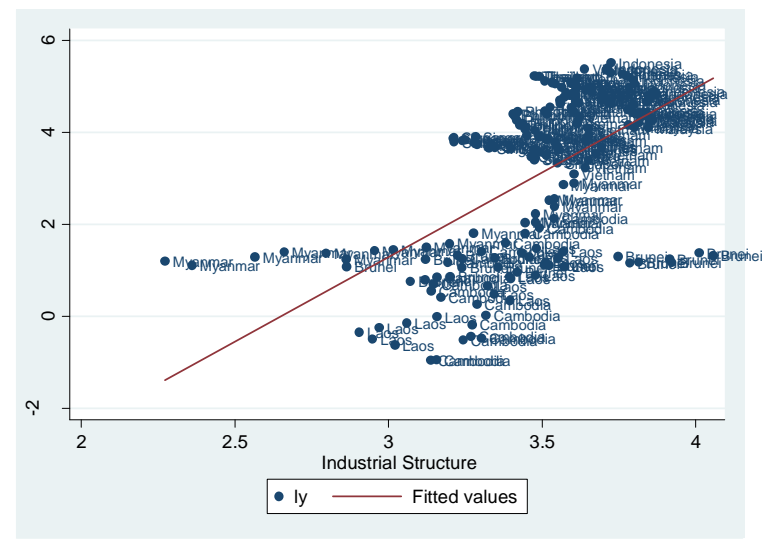

Fig.2.c Scatter Plot Relationship between Industrial Structure (IND) and Electricity Consumption (EC)

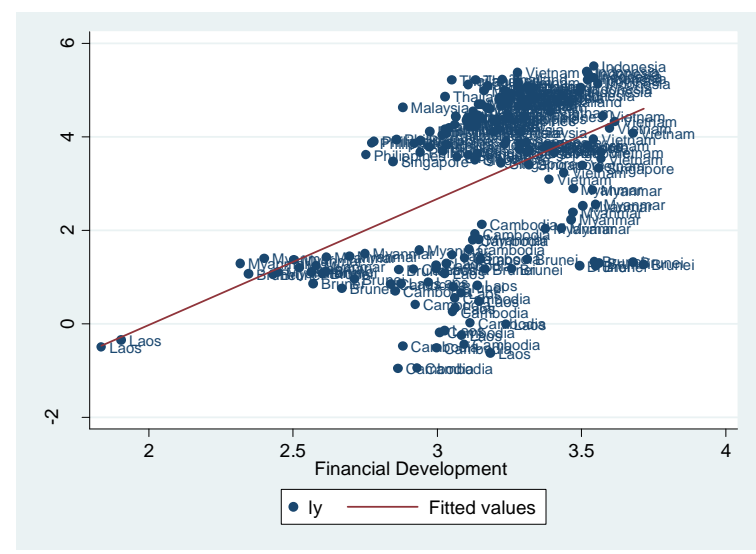

Therefore, the equation of regression logarithm is expressed based on FE estimator as:

$$
E C_{i t}=13.0580+3.6524 U R B_{i t}+0.5040 I N D_{i t}+0.1944 F D_{i t}+\varepsilon_{i t}(\mathbf{5})
$$

The results shows that URB are strongly significant influencing EC (99\%), the positive relationship as URB increase by $1 \%$ resulted that EC hanged at coefficient 3.642736. URB is the proxy of percentage of urban over population, means that regardless the higher population, the impact of urban is strongly influencing the electricity consumption. The result implies that the country with higher urbanization required more energy to fulfil need in urban. This finding is similar to study done by Al-Mulali [19] in Middle East and North African (MENA) countries and Zhang [20] in China.

Table 4: Estimate Result

\begin{tabular}{|c|c|c|c|c|}
\hline & (1) & (2) & (3) & (4) \\
\hline & $\mathbf{S}$ & $\mathrm{WE}^{\text {FE- }}$ & RE & $\begin{array}{c}\text { FE- } \\
\text { ROBUST }\end{array}$ \\
\hline $\ln$ & 0.893 & 3.652 & 3.422 & 3.65241 \\
\hline \multirow[t]{3}{*}{ URB } & $976 * * *$ & $417 * * *$ & $187 * * *$ & $7 * *$ \\
\hline & $(0.21$ & $(0.27$ & $(0.26$ & \\
\hline & 3) & 3) & 8) & $(1.455)$ \\
\hline $\ln$ & 2.548 & 0.504 & 0.518 & 0.50407 \\
\hline \multirow[t]{3}{*}{ IND } & $013 * * *$ & $073 * * *$ & $220 * * *$ & $3 *$ \\
\hline & $(0.45$ & $(0.14$ & $(0.15$ & \\
\hline & 0) & 9) & 3) & $(0.261)$ \\
\hline $\ln$ & 1.082 & 0.194 & 0.214 & 0.19440 \\
\hline
\end{tabular}




\begin{tabular}{|c|c|c|c|c|}
\hline \multirow{2}{*}{ FD } & $719 * * *$ & $400 *$ & $845^{*}$ & 0 \\
\hline & 9) & 3) & 6) & $(0.218)$ \\
\hline tant & $\begin{array}{l}- \\
12.56137 \\
5 * * *\end{array}$ & \begin{tabular}{l}
\multicolumn{1}{c}{} \\
13.05807 \\
$5^{* * *}$
\end{tabular} & \begin{tabular}{l}
\multicolumn{1}{c}{} \\
12.31457 \\
$2^{* * *}$
\end{tabular} & $\begin{array}{c}- \\
13.058075^{* *}\end{array}$ \\
\hline & 5) & 2) & 0) & (5.067) \\
\hline $\begin{array}{l}\text { Obse } \\
\text { rvations }\end{array}$ & 188 & 188 & 188 & 188 \\
\hline $\begin{array}{c}\text { R- } \\
\text { squared }\end{array}$ & $259^{0.425}$ & $673^{0.594}$ & & $3 \quad 0.59467$ \\
\hline $\begin{array}{l}\quad \text { Adj. } \\
\text { R- } \\
\text { squared }\end{array}$ & 0.416 & 0.567 & & 0.588 \\
\hline $\begin{array}{l}\text { F- } \\
\text { Test }\end{array}$ & $* * *$ & $* * *$ & & * $9.171 * *$ \\
\hline chi2 ${ }^{\text {Wald }}$ & & & 238.8 & \\
\hline
\end{tabular}

Note: Standard errors in parentheses

$* * * \mathrm{p}<0.01, * * \mathrm{p}<0.05, * \mathrm{p}<0.10$, indicate the significant level.

The increase $1 \%$ in industrial structure is expected to drive $0.504 \%$ changes in the electricity consumption. Thus, it reflects that although the flat curve for industrialization trend among ASEAN countries, the electricity consumption still moving upwards associated with urban population factors. Similar finding from Shahbaz and Lean [13], the growth in industrialization leads more financial services, and at the same time boost electricity consumption in respective country.

The impact of financial development gives less influence compared to the other two variables, where significant value at $\mathrm{p}<10 \%$ and coefficient at 0.1944 . However, the government should acknowledge the role financial investment in expanding the technology lead to better energy efficiency. The previous study, the interaction in financial development leads the country to choose high technology innovation and it synchronizes with theory of ecological modernization [21-22]. The transformation of traditional industry implies the major technology adoption while balancing between the environment impact.Diagnostic test also run to confirm that Multicollinearity, Heteroscadisity and Serial Correlation within control.

Table 5: Least Square Dummy Variable (LSDV) for Fixed Effect-Within estimation (FE-WE)

\begin{tabular}{ll}
\hline VARIABLES & FE-WE \\
\hline URB & $3.652417 * * *$ \\
& $(0.273)$ \\
IND & $0.504073^{* * *}$ \\
& $(0.149)$ \\
FD & $0.194400^{*}$ \\
Cambodia & $(0.113)$ \\
& $4.283571^{* * *}$ \\
Indonesia & $(0.369)$ \\
& $5.128283^{* * *}$ \\
Laos & $(0.170)$ \\
& $3.035719^{* * * *}$ \\
Malaysia & $(0.284)$ \\
& $3.528178^{* * *}$ \\
& $(0.115)$ \\
& \\
&
\end{tabular}




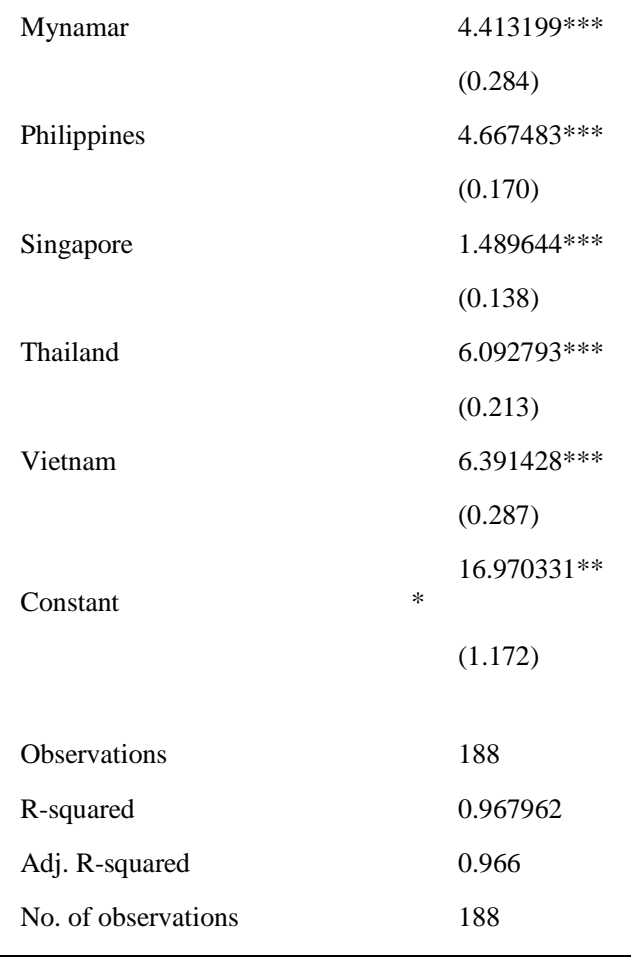

Another method to estimate using Fixed Effect is through Least Square Dummy Variable (LSDV) to capture country-specific effects (heterogeneity). Thus, the maximum individual (country) dummies are $9(\mathrm{~N}-1)$. Table 5 explains the regression result Country_9 (Thailand) and Country_10 (Vietnam) have the highest positive intercept with 6.0927 and 6.3914 respectively. However, Country_8 (Singapore) has the lowest intercept 1.4894 although the urban population is $100 \%$, this could explain that wealthier population tend to consume less electricity consistent with the theory of ecological modernization and urban transition.The model also explained that using country dummies have greater R-square with $96.7 \%$ independent variable influence the electricity consumption.

\section{Conclusion}

This study provide new evidence of panel data analysis in examining the impact of urban population, industrial structure, and financial development significantly attribute of electricity consumption. The empirical result explains that the situation of ASEAN countries are derived electricity consumption and it is part of process in economics development to sustain vulnerable living. In addition, the reliance of fossil fuels create environmental concern among industrialized and developing nations on imported oils and it exposes the consumer to volatile fluctuate all the time.

Thus, the finding this study recommends for policy makers to explore new sources of electricity production and ensure the sustainability of energy. It is worrying. As for the case of Myanmar, the country has registered the lowest electricity rate (50\%) in 2019. Encouragement of mix renewable energy is expected to give a better energy access and reduce the cost of distribution and transmission in rural area. Learning from the case of Thailand and Vietnam, a strong financing system promote more energy efficiency in household and adoption of the renewable energy technology. Such that, government should encourage more participation of consumer investment in self-generating electricity through rooftop solar PV.

Going forward, there will be more studies identifying the potential of households in reducing the burden of government in producing electricity. It is also suggested to examine relationship of urban population and renewable energy in order to see acceptance of new technology among the society. Another question is whether the effect of financial development could ease the growth of renewable energy in future?

\section{Acknowledgements}

The authors would like to give grateful to UNITEN R\&D Sdn. Bhd. for providing facilities and financial support through TNB Seeding Fund (U-TR-RD-19-26) and Institute Energy Policy and Research (IEPRe), Universiti Tenaga Nasional, Selangor, Malaysia for giving the technical support. This study also part of Thesis in Master of Science in Finance. 


\section{References}

Asian Development Bank, (2020), Key Indicators for Asia and the Pacific 2020. Available from https://kidb.adb.org/

Vithayasrichareon, P., MacGill, I. F., \& Nakawiro, T. (2012). Assessing the sustainability challenges for electricity industries in ASEAN newly industrialising countries. Renewable and Sustainable Energy Reviews, 16(4), 2217-2233.

ASEAN-German Energy Programme, (2021), AGEP Newsletter \#14 - January 2021. ASEAN Centre for Energy (ACE). Available from https://aseanenergy.org/agep-newsletter-14-january-2021/

Ramli, M., Mohd Saad, N., Abdullah, Z., (2020). Encouraging Solar PV Investment as One of Renewable Energy in Malaysia. Global Business and Management Research (GBMR): An International Journal Vol. 12(4), pp. 149-159

Asian Development Bank, (2020), Key Indicators for Asia and the Pacific 2020. Available from https://kidb.adb.org/

Umurzakov, U., Mirzaev, B., Salahodjaev, R., Isaeva, A., \& Tosheva, S. (2020). Energy Consumption and Economic Growth: Evidence from Post-Communist Countries. International Journal of Energy Economics and Policy, 10(6), 59.

Duarte, R., Jiménez, S., Langarita, R., \& Sánchez-Chóliz, J. (2015). A CGE model for Spain: effects of reducing electricity tariffs.

Ridzuan, A. R., Kamaluddin, M., Ismail, N. A., Razak, M. I. M., \& Haron, N. F. (2020). Macroeconomic Indicators for Electrical Consumption Demand Model in Malaysia. International Journal of Energy Economics and Policy, 10(1), 16.

Sharif Ali, S. S., Razman, M. R., \& Awang, A. (2020). The nexus of population, growth domestic product growth, electricity generation, electricity consumption and carbon emissions output in Malaysia. International Journal of Energy Economics and Policy, 10(3), 84-89.

Keho, Y. (2016). What drives energy consumption in developing countries? The experience of selected African countries. Energy Policy, 91, 233-246.

Ali, H. S., Nathaniel, S. P., Uzuner, G., Bekun, F. V., \& Sarkodie, S. A. (2020). Trivariate modelling of the nexus between electricity consumption, urbanization and economic growth in Nigeria: fresh insights from Maki Cointegration and causality tests. Heliyon, 6(2), e03400.

Sari, R., Ewing, B. T., \& Soytas, U. (2008). The relationship between disaggregate energy consumption and industrial production in the United States: an ARDL approach. Energy Economics, 30(5), 2302-2313.

Sankaran, A., Kumar, S., Arjun, K., \& Das, M. (2019). Estimating the causal relationship between electricity consumption and industrial output: ARDL bounds and Toda-Yamamoto approaches for ten late industrialized countries. Heliyon, 5(6), e01904.

Shahbaz, M., \& Lean, H. H. (2012). Does financial development increase energy consumption? The role of industrialization and urbanization in Tunisia. Energy policy, 40, 473-479.

Topcu, E., Altinoz, B., \& Aslan, A. (2020). Global evidence from the link between economic growth, natural resources, energy consumption, and gross capital formation. Resources Policy, 66, 101622.

Kwakwa, P. A. (2020). The long-run effects of energy use, urbanization and financial development on carbon dioxide emissions. International Journal of Energy Sector Management.

Baltagi, B. H. (2005). Econometric analysis of data panel. England: John Wiley \& Sons Ltd.

Law, S. H. (2018). Applied panel data analysis: Short panels. University Putra Malaysia Press, Serdang.

Mohd Saad, N., Ibrahim, J., Husin, N. M., Abdullah, Z., (2020). The Impact of Electricity Tariff towards Cost of Production among Sectors in Malaysia. Global Business and Management Research (GBMR): An International Journal Vol. 12(4), pp. 497-503

Al-Mulali, U., Fereidouni, H. G., Lee, J. Y., \& Sab, C. N. B. C. (2013). Exploring the relationship between urbanization, energy consumption, and $\mathrm{CO} 2$ emission in MENA countries. Renewable and Sustainable Energy Reviews, 23, 107-112.

Zhang, M., Zhang, K., Hu, W., Zhu, B., Wang, P., \& Wei, Y. M. (2020). Exploring the climatic impacts on residential electricity consumption in Jiangsu, China. Energy Policy, 140, 111398.

Buttel, F. H. (2000). Ecological modernization as social theory. Geoforum, 31(1), 57-65.

Lidskog, R., \& Elander, I. (2012). Ecological modernization in practice? The case of sustainable development in Sweden. Journal of Environmental Policy \& Planning, 14(4), 411-427. 